\title{
BMJ Open Spatial pattern of COVID-19 in Bangladesh: an ecological study
}

\author{
Jahirul Islam (D) , ${ }^{1}$ Xiya Guo (D) , ${ }^{1}$ Md Ahasan Ali, ${ }^{2}$ Md Ashraful Islam, ${ }^{3}$ Xin Qi, ${ }^{1}$ \\ Guihua Zhuang ${ }^{1}$
}

To cite: Islam J, Guo X, Ali MA, et al. Spatial pattern of COVID-19 in Bangladesh: an ecological study. BMJ Open 2021;11:e047566. doi:10.1136/ bmjopen-2020-047566

- Prepublication history for this paper is available online. To view these files, please visit the journal online (http://dx.doi. org/10.1136/bmjopen-2020047566).

Received 03 January 2021 Accepted 13 December 2021

Check for updates

(C) Author(s) (or their employer(s)) 2021. Re-use permitted under CC BY-NC. No commercial re-use. See rights and permissions. Published by BMJ.

${ }^{1}$ School of Public Health, Xi'an Jiaotong University, Xi'an, Shaanxi, China

${ }^{2}$ School of Basic Medical Sciences, Xi'an Jiaotong University, Xi'an, Shaanxi, China ${ }^{3}$ Department of Public Health, Bangladesh Open University, Gazipur, Bangladesh

Correspondence to Dr Xin Qi; xin.qi@xjtu.edu.cn

\section{ABSTRACT}

Objective To analyse the spatial clustering of COVID-19 case fatality risks in the districts of Bangladesh and to explore the association of sociodemographic indicators with these risks.

Study design Ecological study.

Study setting Secondary data were collected for a total of 64 districts of Bangladesh.

Methods The data for district-wise COVID-19 cases were collected from the Ministry of Health and Family Welfare, Bangladesh from March 2020 to June 2020. Socioeconomic and demographic data were collected from National Census Data, 2011. Retrospective spatial analysis was conducted based on district-wise COVID-19 cases in Bangladesh. Global Moran's / was adopted to find out the significance of the clusters. Furthermore, generalised linear model was conducted to find out the association of COVID-19 cases with sociodemographic variables.

Results Total 87054 COVID-19 cases were included in this study. The epidemic hotspots were distributed in the 11 most populous cities. The most likely clusters are primarily situated in the central, south-eastern and north-western regions of the country. High-risk clusters were found in Dhaka (Relative Risk (RR): 5.22), Narayanganj (RR: 2.70), Chittagong (RR: 1.69), Munshiganj (RR: 2.31) Cox's Bazar (RR: 1.63), Faridpur (RR: 1.65), Gazipur (RR: 1.33), Bogra (RR: 1.35), Khulna (RR: 1.22), Barishal (RR: 1.07) and Noakhali (RR: 1.06). Weekly progression of COVID-19 cases showed spatially clustered by Moran's I statistics ( $p$ value ranging from 0.013 to 0.436 ). After fitting a Poisson linear model, we found a positive association of COVID-19 with floating population rate $(\mathrm{RR}=1.542,95 \% \mathrm{Cl}$ 1.520 to 1.564$)$, and urban population rate $(\mathrm{RR}=1.027,95 \% \mathrm{Cl}$ 1.026 to 1.028$)$.

Conclusion This study found the high-risk cluster areas in Bangladesh and analysed the basic epidemiological issues; further study is needed to find out the common risk behaviour of the patients and other relative issues that involve the spreading of this infectious disease.

\section{BACKGROUND}

The Coronavirus Disease 2019 (COVID-19) is an emerging infectious disease that was announced as a pandemic by the WHO on 11 March $2020 .{ }^{1}$ COVID-19 is caused by infection of severe acute respiratory syndrome (SARS) CoV-2, a novel coronavirus that belongs to single-stranded RNA virus ${ }^{2}$ as well as $\beta$ coronavirus that is caused by the zoonosis mood of transmission. SARS caused by SARS-associated coronavirus
Strengths and limitations of this study

This study analysed the spatial distribution of COVID-19 incidence rate in the districts of Bangladesh and explored the association with the socioeconomic and demographic indicators.

- Global Moran's I was used to determine spatial autocorrelation.

- Our research looked at the issue from a geographical standpoint, which might lead to new ideas for combating the COVID-19 epidemic throughout the world.

- Population and socioeconomic data, including floating population, were obtained from the 2011 Census due to availability of data, which may cause bias.

- The COVID-19 data did not identify imported or local transmitted cases.

(SARS-CoV) in 2013 and 2012 Middle East Respiratory Syndrome (MERS) have the same origin as COVID-19 and the fatality rate was $10 \%$ for SARS-CoV and $37 \%$ for MERS-CoV ${ }^{3}$ 4 although the mortality and fatality rates can be varied country-wise. The novel coronavirus is identified as SARS CoV-2 because SARS-CoV and SARS CoV-2's protein shares $76.47 \%$ of amino acid sequence identity. ${ }^{5}$

As of 31 May 2020, the number of patients infected by COVID-19 worldwide was 5934 936 , the number of people who died is 367 $166 .{ }^{6}$ The disease is believed to have spread from a wholesale fish market situated inside Wuhan city, named Hunan Sea Food Market. The first confirmed cases were found in Wuhan on 24 January 2020, from the sample of three patients showing symptoms of pneumonia. After the detection of this new coronavirus, the first wave was seen in China where 91 701 active cases were found and 4746 people have already died. ${ }^{7}$ Outside China, the first case was found in Thailand on 8 January as that person has been travelling from Wuhan. ${ }^{8}$ Within 2 February, COVID-19 expanded to many countries like India, Philippines, Russia, Spain, Sweden, the UK, Australia, Canada, Germany, Japan, Singapore, the USA, the UAE and Vietnam. ${ }^{9}$ And as of 31 
May, almost all of the countries in the world were affected by this virus. Until 20 September, by case number, USA (6764970), India (5308014), Brazil (4528240), Russia (1092915) had the highest number. By the number of deaths reported, USA (199259), Brazil (136532), India (85619) and Mexico (73258) have the highest number. ${ }^{7}$

The exact source of the COVID-19 is still unknown; ${ }^{10}$ therefore, bats seem to be one of the prime suspects as the previously same type of zoonotic diseases have spread from bats. Some suggest that pangolins may be a possible source of the virus transmitted through the direct or indirect host. ${ }^{11} \mathrm{Up}$ to 21 September, the mortality rate for SARS-Cov- 2 is $3.10 \%{ }^{12}$ and the mortality rate is changing gradually. Although this virus has a non-human source of infection, the transmission can be held human to human via direct contact by air droplets from another infected individual ${ }^{13}$ or by indirect contact like touching contaminated objects, inhaling contaminate air, even personal protective equipment can be the source of contamination. ${ }^{14}$ Symptoms may include fever, fatigue, dry cough, anorexia, myalgia, dyspnoea, diarrhoea, nausea, dizziness, vomiting and so on. ${ }^{15} 16$

\section{COVID-19 situation in Bangladesh in brief}

Until 21 September, the total number of clinically confirmed cases in Bangladesh is 347372, and 4913 people died due to COVID-19, the number of recovered people is 256565 . According to the data, in 2019, about 700159 Bangladeshi expatriates are working overseas in many European and middle east countries. ${ }^{17}$ As Europe became the epicentre of COVID-19 after China, ${ }^{18}$ expatriates started to come back to Bangladesh from many parts of the world. Due to the lack of safety measures, quarantine facilities inside and outside the airport of Bangladesh, it was hard to control the spread of COVID-19. The first case of Bangladesh was found on the 8 March 2020. The patients are expatriates who came from Italy and Kuwait. ${ }^{19}$ Later on, the number of infected people gradually increased. At first, there was a lack of labs to perform enough tests but gradually 99 labs were established where 1821270 people were tested and the case detection ratio is $19.5 \%$. As this is an ongoing disease, the infection fatality ratio (IFR) has been calculated as $1.4 \%$. IFR is recommended by WHO to find out the true severity of the disease. ${ }^{20}$ Among the total active cases, $72 \%$ are male and $28 \%$ are female. The capital of the country, Dhaka has a population of about 8906039 and area of 30 551/ sq. $\mathrm{km}$, which consists of $6 \%$ of the total population ${ }^{21}$ and has the highest incidence rate and prevalence as 30124 people are clinically confirmed COVID-19 cases.

Bangladesh is a south-Asian country with 7 divisions and 64 districts. It has an area of about 147570 square kilometres and a population of 162 million $^{22}$ which has made it the eighth most populous country in the world ${ }^{23}$ the population density is 1240 per square $\mathrm{km}^{24}$ About $24.8 \%$ of people live under the poverty line,${ }^{25}$ and the population distribution in the urban and rural areas is consequently $23.3 \%$ and $76.7 \%{ }^{26}$

\section{Bangladesh preparedness and response to COVID-19}

Bangladesh developed health facilities at the tertiary level at the national and divisional levels which are affiliated with medical colleges as well as buildup community clinics by implementing the 4th Health, Population and Nutrition Sector Program (2017-2022). ${ }^{27}$ Besides, the data of WHO say that there is still a shortage of health professionals in Bangladesh. According to the 'SDG index threshold', there should be 4.45 doctors, nurses and midwives per 1000 population, but in Bangladesh, the SDG's Bangladesh progress report, 2018 says that the health worker density is 8.3 per 10000 population which is not enough to meet the demand of the huge population. ${ }^{28}$ Although the first case was announced on 8 March 2020, it is thought that the disease has spread earlier that time. ${ }^{29}$ On 16 March, the government closed all of the educational institutions to control the spread of the virus. On 18 March, National Preparedness and Response Plan was adopted by the Bangladesh government to fight against COVID-19 with a total cost of US\$29 550000 million. Bangladesh announced the first phase of lockdown from 26 March, 18 days after the first case was found. Later on, the lockdown was prolonged until 30 May. Within this time, the number of active cases reached 44608 followed by 610 number of deaths. From 31 May until now, partial lockdown was implemented to let people work by maintaining social distance and precautions. Initially, the COVID-19 test was performed in the Institute of Epidemiology, Disease Control and Research (IEDCR), and a new fully automated RNA extraction machine was delivered to the IEDCR lab. ${ }^{30}$ The testing facility was not enough to test more cases quickly as IEDCR began to decentralise the testing facility outside Dhaka and now there have been established 99 labs around the country. Bangladesh's health ministry is coping with the regulations provided by the $\mathrm{WHO}$ and implementing the interventions by local and international organisations and health resources. The government of Bangladesh also recruited 2654 health service providers, at least 2000 doctors, and 6000 nurses to fight against the ongoing pandemic. $^{31}$

\section{Purpose of our study}

COVID-19 spread in Bangladesh encouraged us to discover the disease distribution district-wise to explain the association of COVID-19 with socioeconomic and demographic indicators.

\section{MATERIALS AND METHOD \\ Study area and design}

Bangladesh is a south-Asian country situated between $20^{\circ} 34^{\prime}$ to $26^{\circ} 38^{\prime}$ north latitude and $88^{\circ} 01^{\prime}$ to $92^{\circ} 41^{\prime}$ east longitude. The maximum extension is about $440 \mathrm{~km}$ in the E-W direction and $760 \mathrm{~km}$ in the NNW-SSE direction. The total area is 147570 square kilometres, with 64 districts, 8 divisions of which were covered in this study. Geographical information system (GIS) was used to 
geo-code the neighbourhood districts level, and surveillance records were tested to avoid misclassification. Moreover, a generalised linear model (GLM) was performed to check the relationship between COVID-19 cases and socioeconomic and demographic variables.

\section{Data collection}

The district-wise COVID-19 number of cases was collected, which was used to measure incidence rate, case fatality ratio. The date was arranged weekly basis and total case format from 8 March to 28 June from the Institute of Epidemiology, Disease Control and Research (IEDCR), working under the Ministry of Health and Family Welfare, Bangladesh.

Predictor variables including socioeconomic and demographic, geographical, population projected data were collected from different sources. Socioeconomic and demographic data including population density $(\mathrm{PD} /$ per square $\mathrm{km}$ ) was collected from national census data 2011, floating population data (Rate_floating) was collected from population distribution and internal migration in Bangladesh, volume-6, BBS, urban population data (Rate_URPOP) was gathered from 'Changing Patterns of Urbanization in Bangladesh: An Analysis of Census Data', Volume-12, BBS. The projected population data were collected from annual TB data 2015-2017. The district's name, code, area $\left(\mathrm{km}^{2}\right)$, longitude and latitude of the centroids associated with each district were collected from the National Census data 2011.

After gathering the raw data, all of them were imported to Microsoft Excel 2016 (Microsoft, Redwoods, Washington, USA) and linked to the respective location in the geographical information system. GIS mapping was performed by GeoDa 1.14.0 software.

\section{Statistical analysis \\ Descriptive analysis}

Descriptive analysis was performed for cumulative aggregated weekly data and socioeconomic and demographic variables. Weekly cumulative case fatality rate (CFR) was calculated by the following formula:

$$
\frac{\text { Cumulative number of weekly deaths }}{\text { Cumulative number of weekly cases }} \times 100
$$

\section{Spatial analysis}

We used the GeoDa tools to generate spatial analyses, and Moran's I index. These all assist to verify whether the case distribution is scattered, dispersed or random. ${ }^{32}$

The spatial weights matrix was used to describe the geographical connections between the districts. For spatial weights, we used a first-order queen continuity weights matrix, which defines neighbours as those that have a common boundary or vertex. Using the districtlevel polygon-shaped dataset, a queen weights matrix was created in GeoDa. The Moran's I statistic is perhaps the most widely used measure of global spatial autocorrelation. It is a cross-product statistic between a variable and its spatial lagged version, with the variable represented in $\mathrm{SD}$ from the mean. The Moran's $I$ is represented as

$$
I=\frac{\sum_{i} \sum_{j} W_{i j} Z_{i} \cdot Z_{j} / S_{0}}{\sum_{i} Z_{I}^{2} / n}
$$

For and observation at location $i$, this is expressed as $Z_{i}=x i-\bar{x}$, where $\bar{x}$ is the mean of variable $x$, with $w_{i j}$ as the elements of the spatial weights matrix where, $S_{0}=\sum_{i} \sum_{j} W_{i j}$ is the sum of all the weights, and $n$ as the number of observations. The randomisation was followed by 999 permutations and pseudo $p$ value. The formula is

$$
\mathrm{p}=\frac{R+1}{M+1}
$$

where $R$ represents the number of times the computed Moran's I from the spatial random data sets (the permuted data sets) is equal to or more extreme than the observed statistic. $M$ equals the number of permutations. The latter is typically taken as 99999 and so on, to yield nicely rounded pseudo $p$ values.

The pseudo $p$ value is only a summary of the result from the reference distribution and should not be interpreted as an analytical $p$ value. GIS and mapping have been applied to find out the distribution of incidence rate district-wise. We obtained the map of the incidence rate district-wise for 28 June in GeoDa software. To measure spatial autocorrelation in the COVID-19 case by location, Moran's I was performed by GeoDa. To test the significance of Moran's I index, we did randomisation by limiting our data to 999 permutations as it is considered sufficient for reliable inference. Location data indicate the latitude and longitude of each district. In our cases, we used the centroids of latitude and longitude for 64 districts that represent the country Bangladesh. To see if there were any statistically significant geographical clusters of COVID-19, we used SaTScan v9.6 to conduct spatial scan statistical analysis based on Kulldorf cluster detection. ${ }^{33} 34$ Case, population and coordinate data were used as inputs to SaTScan for purely spatial analysis.

The number of occurrences in a given region is Poisson distributed according to a known underlying population at risk, including a Poisson-based model. ${ }^{35}$ For the floating population and urbanisation data, the rate was measured and used for descriptive study and GLM. In the GLM, we used normalised population density data, floating population raw data were collected, and then the standardised rate was measured by the following formula:

$$
\frac{\text { Number of floating population }}{\text { Projected population }} \times 1000
$$

Similarly, the urban population rate was measured by

$$
\frac{\text { Urban population }}{\text { Projected population }} \times 100
$$

\section{Patient and public involvement}

COVID-19 in Bangladesh is a major concern due to the mass spread of this disease throughout the country. We collected available online data from the relevant authority under 'Ministry of Health and Family Welfare'. No patients were directly involved in our study. We just collected the district-wise aggregate data for the active number of COVID-19 cases. As this is a cross-sectional study, no patients were recruited for our study. 
Table 1 Descriptive analysis of COVID-19 data and other indicators

\begin{tabular}{lllllcr}
\hline & Mean & SD* & Minimum & Maximum & Moran's I & P value \\
\hline Area $\left(\mathrm{km}^{2}\right)$ & 2307.34 & 1184.16 & 2011.54 & 2603.14 & 0.313 & 0.001 \\
\hline Population projected & 2528489 & 2102615 & 461221 & 14902369 & 0.035 & 0.211 \\
Population density (per $\left.\mathrm{km}^{2}\right)$ & 1124 & 1057 & 87 & 8229 & 0.239 & 0.004 \\
Urban population rate (\%) & 15.59 & 7.54 & 3.68 & 39.81 & -0.003 & 0.406 \\
Floating population rate (per 1000) & 0.65 & 0.61 & 0.07 & 2.95 & 0.190 & 0.018 \\
\hline
\end{tabular}

Note: Data were measured district-wise.

\section{RESULTS}

\section{Descriptive analysis and trend of COVID-19 prevalence and} incidence

In our study period from 8 March to 28 June, the total number of clinically confirmed patients was 137787,1738 people have died and 55727 patients are recovered. The descriptive statistics of the variables used in our study are illustrated in table 1 . The daily number of cases affected, recovered and deaths along with the important decision made by the government during the study period is shown in figure 1.

Table 2 illustrates the weekly progression of COVID-19 in Bangladesh. The CFR was highest in week 3 (10.42\%) may be due to the poor management of new cases. The CFR for week 16 is $1.26 \%$. From week 5 , CFR showed a decreasing trend. In figure 2, we can see that dramatic change in new cases from April to May as the case number increased four times higher. For June, the case number increased two times higher than in May.

Dhaka city has the highest number of active cases, 30124 patients (IR: 202/100 000), it is considered the epicentre of the country. The next highest number of the case was noticed in the Chittagong district with 7466 number of infected cases (IR: 87.96/100 000). Both Dhaka and Chittagong districts are most economically active. Except for Dhaka and Chittagong, districts like Narayanganj (IR:

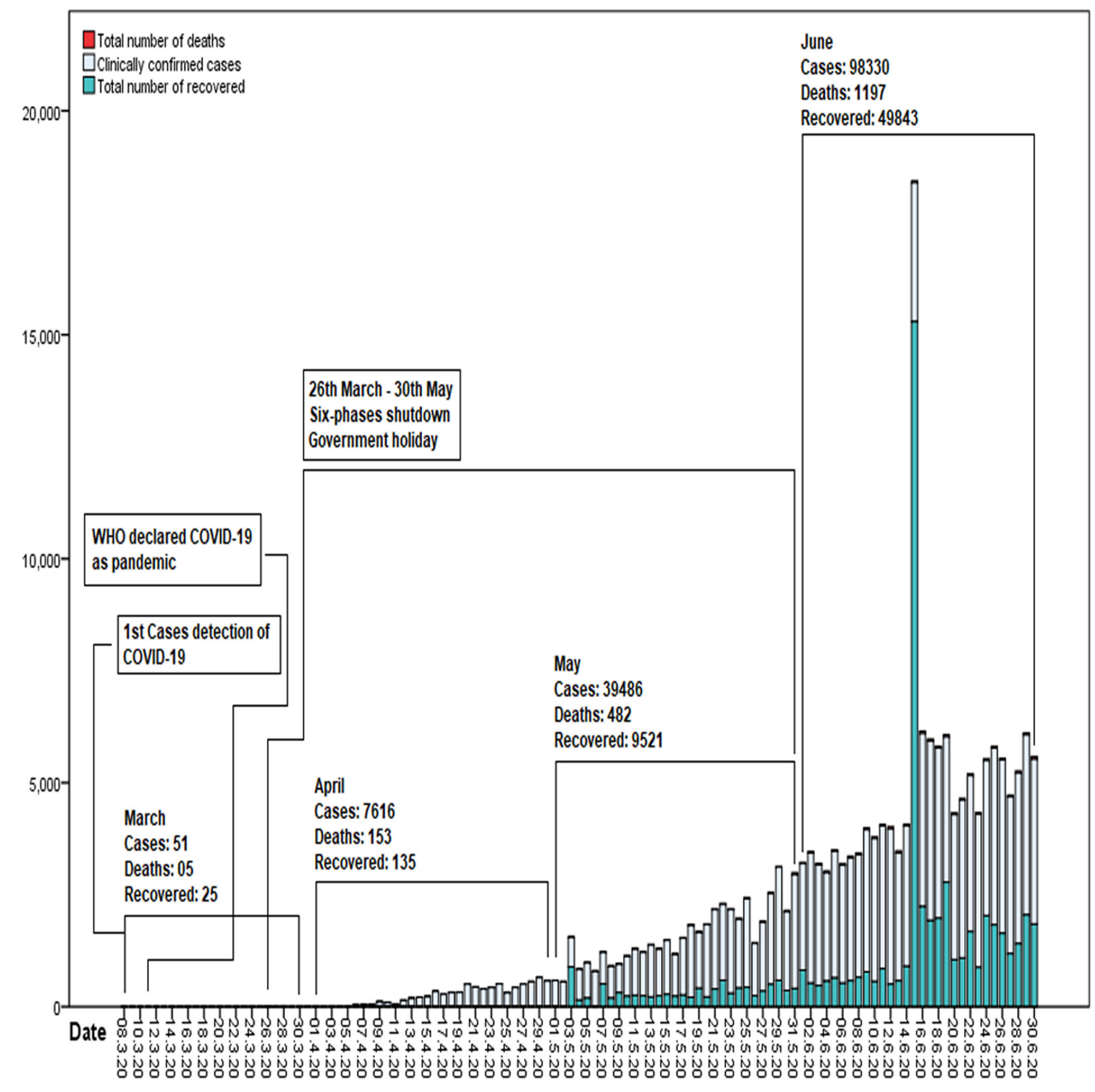

Figure 1 Daily progression of new cases, recovery and deaths. 
Table 2 Weekly progression of COVID-19 in Bangladesh

\begin{tabular}{|c|c|c|c|c|c|c|c|c|c|c|c|c|c|c|c|c|}
\hline & $\begin{array}{l}\text { Week } \\
1\end{array}$ & $\begin{array}{l}\text { Week } \\
2\end{array}$ & Week 3 & Week 4 & $\begin{array}{l}\text { Week } \\
5\end{array}$ & $\begin{array}{l}\text { Week } \\
6\end{array}$ & $\begin{array}{l}\text { Week } \\
7\end{array}$ & $\begin{array}{l}\text { Week } \\
8\end{array}$ & $\begin{array}{l}\text { Week } \\
9\end{array}$ & Week 10 & $\begin{array}{l}\text { Week } \\
11\end{array}$ & Week 12 & Week 13 & $\begin{array}{l}\text { Week } \\
14\end{array}$ & $\begin{array}{l}\text { Week } \\
15\end{array}$ & $\begin{array}{l}\text { Week } \\
16\end{array}$ \\
\hline & $\begin{array}{l}15 \\
\text { March }\end{array}$ & $\begin{array}{l}22 \\
\text { March }\end{array}$ & $\begin{array}{l}29 \\
\text { March }\end{array}$ & 5 April & $\begin{array}{l}12 \\
\text { April }\end{array}$ & $\begin{array}{l}19 \\
\text { April }\end{array}$ & $\begin{array}{l}26 \\
\text { April }\end{array}$ & 3 May & $\begin{array}{l}10 \\
\text { May }\end{array}$ & 17 May & 24 May & 31 May & 7 June & 14 June & $\begin{array}{l}21 \\
\text { June }\end{array}$ & 28 June \\
\hline $\begin{array}{l}\text { Clinically } \\
\text { confirmed }\end{array}$ & 5 & 22 & 21 & 40 & 533 & 1835 & 2960 & 4049 & 5202 & 7611 & 11342 & 13543 & 18616 & 21751 & 24786 & 25481 \\
\hline Total deaths & 0 & 1 & 4 & 4 & 25 & 57 & 54 & 32 & 51 & 100 & 152 & 170 & 238 & 283 & 293 & 274 \\
\hline $\begin{array}{l}\text { Total } \\
\text { recovered }\end{array}$ & 4 & 0 & 11 & 15 & 9 & 36 & 47 & 941 & 1587 & 1723 & 2528 & 2880 & 4122 & 4828 & 26346 & 10650 \\
\hline CFR & 0 & $3.70 \%$ & $10.42 \%$ & $10.23 \%$ & $5.48 \%$ & $3.71 \%$ & $2.68 \%$ & $1.87 \%$ & $1.56 \%$ & $1.47 \%$ & $1.43 \%$ & $1.38 \%$ & $1.88 \%$ & $1.34 \%$ & $1.30 \%$ & $1.26 \%$ \\
\hline
\end{tabular}

CFR, case fatality rate.

140.19/100 000), Munshiganj (IR: 122.46/100 000), Faridpur (IR: 88.09/100 000), Cox's Bazar (IR: 86.83/100 000) have the highest number of incidence rate. The map corresponding to the IR showed in figure 2 illustrates the progression of the disease from 8 March and on 28 June 2020, the central region, north-eastern region, southern region, south-western region and south-eastern region of Bangladesh have the highest incidence rate.

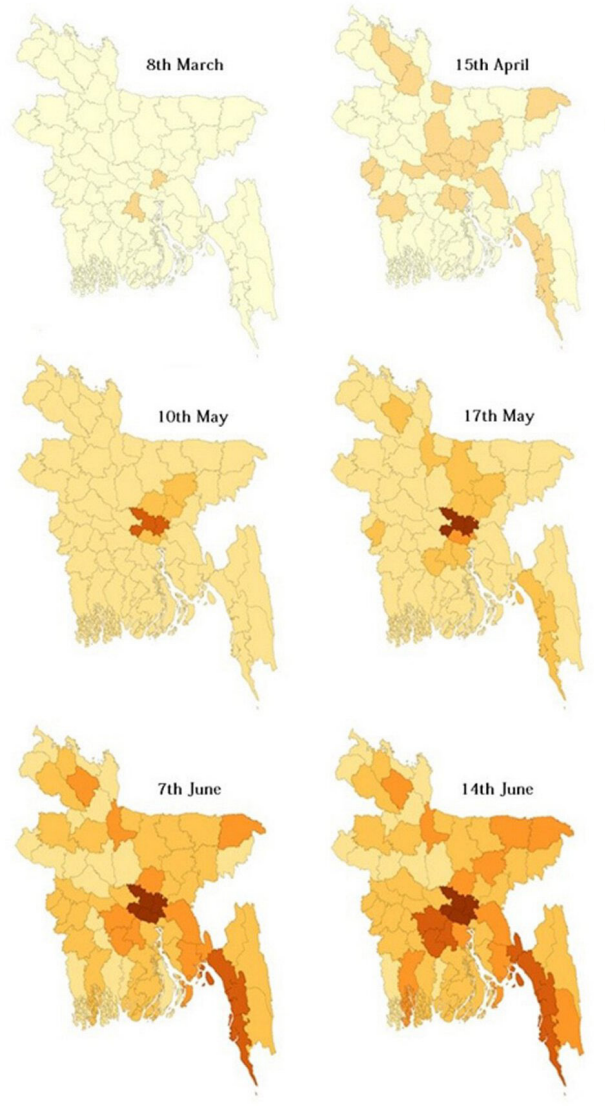

\section{Spatial pattern of COVID-19 cases}

To analyse the spatial risk ratio of the COVID-19 cases in Bangladesh, we performed spatial scanning analysis using SaTScan. By setting a $25 \mathrm{~km}$ radius and taking $50 \%$ population at risk, we ran an analysis which is illustrated in table 3. As of 28 June, the higher risk cluster area by analysis is Dhaka (RR: 5.22), the district Narayanganj district has a higher risk ratio after Dhaka district (RR: 2.70). Both Dhaka and Narayanganj districts are situated in the central region of the country. Table 3 is showing other

Figure 2 Geographical distribution of COVID-19 in Bangladesh. 
Table 3 Information about high risks cluster at the district level

\begin{tabular}{|c|c|c|c|c|c|c|c|c|c|}
\hline & $\begin{array}{l}\text { Cluster } \\
\text { location }\end{array}$ & $\begin{array}{l}\text { Cluster } \\
\text { radius (km) }\end{array}$ & Area $\left(\mathrm{km}^{2}\right)$ & $\begin{array}{l}\text { Population } \\
\text { projected }\end{array}$ & $\begin{array}{l}\text { Number of } \\
\text { cases }\end{array}$ & $\begin{array}{l}\text { Expected } \\
\text { cases }\end{array}$ & RR & $95 \% \mathrm{Cl}$ & $\mathrm{P}$ value \\
\hline $\begin{array}{l}\text { Primary (28 } \\
\text { June) }\end{array}$ & Dhaka & 0 & 1464 & 14902369 & 30124 & 8016.83 & 5.22 & 5.14 to 5.29 & $<0.001$ \\
\hline \multirow[t]{7}{*}{ Secondary } & Narayanganj & 0 & 700 & 3581619 & 5021 & 8016.83 & 2.70 & 2.63 to 2.78 & $<0.001$ \\
\hline & Chittagong & 0 & 5282 & 8487703 & 7466 & 4566.02 & 1.69 & 1.66 to 1.74 & $<0.001$ \\
\hline & Munshiganj & 0 & 1004 & 1587462 & 1944 & 853.99 & 2.31 & 2.20 to 2.41 & $<0.001$ \\
\hline & Faridpur & 0 & 2052 & 2074050 & 1827 & 1115.75 & 1.65 & 1.58 to 1.73 & $<0.001$ \\
\hline & Gazipur & 0 & 1806 & 4608125 & 3270 & 2478.97 & 1.33 & 1.29 to 1.38 & $<0.001$ \\
\hline & Bogra & 0 & 2898 & 3758332 & 2713 & 2021.82 & 1.35 & 1.30 to 1.41 & $<0.001$ \\
\hline & Khulna & 0 & 4394 & 2377776 & 1551 & 1279.14 & 1.22 & 1.16 to 1.28 & $<0.001$ \\
\hline
\end{tabular}

areas with active cases cluster and higher risk ratio for example, Chittagong (RR: 1.69), Munshiganj (RR: 2.31), Cox's Bazar (RR: 1.63), Faridpur (RR: 1.65), Gazipur (RR: 1.22), Bogra (RR: 1.35), Khulna (RR: 1.22), Barishal (RR: 1.07) and Noakhali (RR: 1.06). Most of the highrisk clusters were notified in the central, north-eastern, south-eastern, southern and south-western regions of Bangladesh.

Moreover, we used the Global Moran's I statistics for each week mentioned in table 2 independently to determine the degree of the geospatial autocorrelation and clusters of the outcome variable. The prevalence of positive geographical clustering of COVID-19 cases in the 64 districts was shown by a global spatial correlation study ( $\mathrm{p}$ value ranging from 0.013 to 0.436 ) (table 4 ).

Table 4 Global spatial autocorrelation of COVID-19 cases in Bangladesh

\begin{tabular}{lccl}
\hline Weeks & Moran's I & Z score & P value \\
\hline Week 1 & -0.029 & -0.2632 & 0.436 \\
Week 2 & 0.090 & 2.5116 & 0.049 \\
Week 3 & 0.113 & 3.8296 & 0.013 \\
Week 4 & 0.080 & 3.4456 & 0.018 \\
Week 5 & 0.058 & 3.2013 & 0.021 \\
Week 6 & 0.077 & 2.9062 & 0.036 \\
Week 7 & 0.037 & 2.3581 & 0.035 \\
Week 8 & 0.043 & 2.4551 & 0.034 \\
Week 9 & 0.043 & 2.4033 & 0.034 \\
Week 10 & 0.043 & 2.3933 & 0.032 \\
Week 11 & 0.073 & 2.4825 & 0.031 \\
Week 12 & 0.073 & 2.2439 & 0.040 \\
\hline
\end{tabular}

The association of COVID-19 cases with socioeconomic and demographic variables

The association of COVID-19 cases with socioeconomic and demographic variables was explored using GLM (table 5), and we found positive association of COVID-19 with population density $(\mathrm{RR}=1.762,95 \%$ CI 1.105 to 2.810 ), floating population ( $\mathrm{RR}=1.461,95 \%$ CI 1.171 to $1.824)$, urban population ( $\mathrm{RR}=1.003,95 \% \mathrm{CI} 1.002$ to 1.004) with a good fit.

\section{DISCUSSION}

COVID-19 was first detected in Bangladesh 43 days after it was discovered in China. Expatriates from other nations were returning home since those countries were affected by COVID-19. Because of the large number of expats, the government agreed to enable them to accept home quarantine, meaning they would be separated from their families while at home. On 8 March, three patients with clinically confirmed COVID-19 were identified. ${ }^{36}$ Two of them have come back from Italy and Kuwait. On that particular day, Italy had 6387 active cases and 366 deaths, consequently, Kuwait had 63 active cases with no

Table 5 The association of socioeconomic and demographic variables with COVID-19 cases using GLM

\begin{tabular}{lllllll} 
& & \multicolumn{4}{c}{$\mathbf{9 5 \%} \mathbf{C l}$} & \\
\cline { 4 - 5 } Parameter & Exp(B) & SE & Lower & Upper & P value \\
\hline $\begin{array}{l}\text { Population } \\
\text { density }\end{array}$ & 1.000 & $1.22 \mathrm{E}-6$ & 1.000 & 1.000 & $<0.001$ \\
$\begin{array}{l}\text { Urban } \\
\text { population } \\
\text { rate (\%) }\end{array}$ & 1.027 & 0.0006 & 1.026 & 1.028 & $<0.001$ \\
$\begin{array}{l}\text { Floating } \\
\text { population }\end{array}$ & 1.542 & 0.0073 & 1.520 & 1.564 & $<0.001$ \\
\hline
\end{tabular}

Dependent variable: total COVID-19 Cases.

GLM, generalised linear model. 
death. ${ }^{37}$ On 11 March, WHO announced COVID-19 as a pandemic, ${ }^{38}$ and from 26 March, the government of Bangladesh started government holidays as offices, transportation, educational institutions, religious places and shopping malls were shut down due to control the spread of COVID-19. ${ }^{39}$ As seen in table 2, the number of active cases increased gradually during the first 4 weeks after the detection of the first case. From 12 April, the fifth week after the first case, the active cases increased dramatically to $605.68 \%$ as 533 new clinically confirmed cases were found in a week.

Certainly, Dhaka city has the highest number of clinically confirmed patients with COVID-19 due to massive population density which is situated at the central region. ${ }^{40}{ }^{41}$ The city has 6970105 residents and a population density of 55169 people per square kilometre, whereas the national population density is 976 persons per square kilometre. ${ }^{42}$ Munshiganj district was at high risk since 17 May probably due to the two busiest river ports connecting Dhaka and Munshiganj districts. People used to pass through the ferry with vehicles followed by fewer safety distance concerns. Daily, about 200000 people are engaged in internal water transport for transporting passengers, goods and cargo in Bangladesh. ${ }^{43}$ Narayanganj, Munshiganj, Gazipur and Faridpur districts, which are adjacent to Dhaka city, showed a high-risk ratio. All of these districts pointed out by $25 \mathrm{~km}$ radius using SaTScan tool are the most important districts economically in Bangladesh. The disease transmission may happen because the intertransportation and migration among these city is considerably frequent than others. The higher Z-value and the significant level of Moran's I value is confirming the existence of the spatial cluster of COVID-19 at different parts of the country. Previous studies have found population density ${ }^{44}{ }^{45}{ }^{46}$ unemployment, ${ }^{47}$ wind speed ${ }^{48}$ the elderly population, ${ }^{46}$ urban population, ${ }^{49} 50$ the exported population from the epicentre throughout the country ${ }^{51}$ and so on, are related with the spread of COVID-19 prevalence. Our study showed that urban population may increase the prevalence of the disease due to more activities and movement occurring by people which is also suggested by other authors. ${ }^{52}{ }^{53}$ Furthermore, floating population is significantly associated with COVID-19 cases. The 'Population distribution and internal migration in Bangladesh' data have shown that there is 147674 number of floating population around the country, $68 \%$ of them are from urban areas. ${ }^{13}$ Furthermore, it was a challenge to keep the expatriates quarantined. Therefore, the movement of the mass population including the expatriates at different parts of the country may be played an important role in spreading the disease. ${ }^{54}$

\section{Strengths of the study}

This study explored the spatial pattern in different ways using various cluster radii and considering the socioeconomic and demographic indicators to measure the risk. The high-risk cluster districts sorted out in this research will help the policymakers to initiate appropriate interventions to reduce the cases in those regions.

\section{Limitations of the study}

The limitations of this study should be also mentioned. The sociodemographic data used in this analysis were collected from 2011 census data that can vary during the research period. The real-time weather data were absent, and the health behaviour of individual COVID-19 positive cases should take under research to find out any common behaviour that has led to the spread of this disease. We are expecting more research in the future will be carried out to answer these questions.

\section{CONCLUSION}

COVID-19 in Bangladesh is still a grieve concern. The high-risk districts will show more cases if public health measures are not implemented. Therefore, we hope this study will provide some necessary information about risky clusters. We should also give importance to meteorological factors that are associated with COVID-19 spread and provide support for more risk groups to avoid further progression of this infectious disease. Bangladesh is already in the top 20 countries in the world that have the most active cases. Being a densely populated country, COVID-19 has made it hard to stop immediately. Scientists have also warned about the fourth wave of novel coronavirus which can bring more people to death row. Until the vaccine is invented and implemented, the government, as well as people, should be more conscious about the consequences of this new deadliest disease on the planet.

Some recommendations can be proposed according to the situation. First, we admit that the CFR is still very low in Bangladesh, but the active case number was followed by an increasing trend. It can be reduced by taking more strict measures to refrain people from group activities. The people of Bangladesh are driven by poverty and religious activities. Due to poverty, people do not have any other choices rather going outside to earn their livelihood. Thus, this population should be monitored properly to ensure that they are following the safety distancing rules and properly using masks and hand sanitizers. Security forces, health staff, volunteers can take part to follow up on the safety protocol maintained by people. Those who do follow the rules should be guided to follow the rules. Many religious activities require gathering and should be also eliminated by involving the guidance provided by religious leaders countrywide. For COVID-19 screening, effective testing facilities are needed to detect more hidden cases at the community level. There should be more control over human movement alongside the high-risk cluster districts to avoid further infection and disease progression.

Acknowledgements We acknowledge the School of Public Health, School of International Education, and Xi'an Jiaotong University for their support. Besides, we recognise the contribution from Department of Public Health, Bangladesh Open University. 
Contributors $\mathrm{Jl}$ remained the principal investigator of this study who conceptualised, designed and planned it along with $\mathrm{XQ}, \mathrm{GZ}$ and MAA. The expert opinion was incorporated by $X Q, X G$ and MAA, while MAl was engaged with data acquisition and recoded the data to prepare a clean database with distant assistance. Data were analysed by $\mathrm{JI}$ and MAA in consultation with $\mathrm{XQ}$ and $\mathrm{XG}$. The initial manuscript was drafted by $\mathrm{JI}$ and MAA. The manuscript was finally edited by $\mathrm{Jl}, \mathrm{XQ}, \mathrm{XG}, \mathrm{GZ}$ and MAA. XQ and $\mathrm{Jl}$ worked as the guarantor accepting full responsibility for the work and the conduct of the study, had access to the data, and controlled the decision to publish.

Funding This work was supported by the QINNONG Bank-XJTU Special Project for COVID-19 (QNXJTU-05) and Shaanxi Natural Science Foundation Research (2018JM7091).

Map disclaimer The depiction of boundaries on this map does not imply the expression of any opinion whatsoever on the part of BMJ (or any member of its group) concerning the legal status of any country, territory, jurisdiction or area or of its authorities. This map is provided without any warranty of any kind, either express or implied.

Competing interests None declared.

Patient and public involvement Patients and/or the public were not involved in the design, or conduct, or reporting, or dissemination plans of this research.

Patient consent for publication Not applicable.

Ethics approval The article does not contain the participation of any human being or animal.

Provenance and peer review Not commissioned; externally peer reviewed.

Data availability statement Data are available on reasonable request. The COVID-19 data were collected from https://iedcr.gov.bd/. The sociodemographic and economic data were collected from the Population and Housing Census 2011 http://www.bbs.gov.bd/site/page/47856ad0-7e1c-4aab-bd78-892733bc06eb/ Population-and-Housing-Census For more data, please contact this email: pekfusan@gmail.com.

Open access This is an open access article distributed in accordance with the Creative Commons Attribution Non Commercial (CC BY-NC 4.0) license, which permits others to distribute, remix, adapt, build upon this work non-commercially, and license their derivative works on different terms, provided the original work is properly cited, appropriate credit is given, any changes made indicated, and the use is non-commercial. See: http://creativecommons.org/licenses/by-nc/4.0/.

\section{ORCID iDs}

Jahirul Islam http://orcid.org/0000-0002-1424-5362

Xiya Guo http://orcid.org/0000-0002-1232-098X

\section{REFERENCES}

1 World Health Organization. Virtual press conference on COVID-19 2020;25.

2 Chakraborty I, Maity P. COVID-19 outbreak: migration, effects on society, global environment and prevention. Sci Total Environ 2020;728:138882.

3 Kuiken T, Fouchier RAM, Schutten M, et al. Newly discovered coronavirus as the primary cause of severe acute respiratory syndrome. Lancet 2003;362:263-70.

4 Drosten C, Günther S, Preiser W, et al. Identification of a novel coronavirus in patients with severe acute respiratory syndrome. $N$ Engl J Med 2003;348:1967-76.

$5 \mathrm{Xu} \mathrm{X}$, Chen P, Wang J, et al. Evolution of the novel coronavirus from the ongoing Wuhan outbreak and modeling of its spike protein for risk of human transmission. Sci China Life Sci 2020;63:457-60.

6 World Health Organization. Coronavirus disease (COVID-19), 2020. Available: https://www.who.int/docs/default-source/coronaviruse/ 20200630-covid-19-sitrep-162.pdf?sfvrsn=e00a5466 2

7 World Health Organization. WHO coronavirus disease (COVID-19) dashboard, 2020.

8 World Health Organization. WHO statement on novel coronavirus in Thailand, 2020. Available: https://www.who.int/news-room/detail/1301-2020-who-statement-on-novel-coronavirus-in-thailand

9 Jazeera A. Timeline: how the new coronavirus spread, 2020. Available: https://www.aljazeera.com/news/2020/01/timeline-chinacoronavirus-spread-200126061554884.htm

10 Centers for Disease Control and Prevention. If you have animals, 2020. Available: https://www.cdc.gov/coronavirus/2019-ncov/dailylife-coping/animals.html
11 Chakraborty MKJP. Novel corona virus disease 19 (N COVID-19) epidemic origin, symptoms and precaution measure 2020;31:1395-409.

12 World Health Organization. WHO director-general's opening remarks at the media briefing on COVID-19 2020.

13 Pal M, Berhanu G, Desalegn C, et al. Severe acute respiratory syndrome coronavirus-2 (SARS-CoV-2): an update. Cureus 2020;12:e7423.

14 Liu Y, Ning Z, Chen Y, et al. Aerodynamic characteristics and RNA concentration of SARS-CoV-2 aerosol in Wuhan hospitals during COVID-19 outbreak 2020.

15 Wang D, Hu B, Hu C, et al. Clinical characteristics of 138 hospitalized patients with 2019 novel coronavirus-infected pneumonia in Wuhan, China. JAMA 2020;323:1061.

16 Nie X, Fan L, Mu G, et al. Epidemiological characteristics and incubation period of 7015 confirmed cases with coronavirus disease 2019 outside Hubei Province in China. J Infect Dis 2020;222:26-33.

17 Bereau of Manpower EaT. Overseas employment in 2019: Ministry of expatriates welfare and overseas employment 2019. Available: http:// www.old.bmet.gov.bd/BMET/viewStatReport.action?reportnumber= 33

18 Ceylan Z. Estimation of COVID-19 prevalence in Italy, Spain, and France, science of the total environment. science of the total environment 2020.

19 UNB NEWS. Bangladesh reports first coronavirus death, 2020.

20 World Health Organization. Estimating mortality from COVID-19, 2020. Available: https://www.who.int/news-room/commentaries/ detail/estimating-mortality-from-covid-19

21 Bangladesh Bereau of Statistics. Population projection of Bangladesh dynamics and trends 2011-2061 2015.

22 World Health Organization. Bangladesh 2016. Available: https://www. who.int/countries/bgd/en/

23 Haast B. Population trends and issues Bangladesh. Education About Asia 2019;24.

24 Bank TW. Population density (people per SQ. Km of land area): the world bank, 2018. Available: https://data.worldbank.org/indicator/EN. POP.DNST

25 Bangladesh Planning Commission. Bangladesh progress report 2015,2015

26 Population monograph of Bangladesh [online], 2015. Available: http://203.112.218.65:8008/WebTestApplication/userfiles/Image/ PopMonographs/Volume-6_PDIM.pdf

27 Ministry of Health and Family Welfare. Bangladesh preparedness and response plan for COVID-19, 2020. Available: http://www.mohfw. gov.bd/index.php?option=com_docman\&task=doc_download\&gid= 23359\&lang=en

28 Bangladesh Planning Commission. Sustainable development goals: Bangladesh progress report 2018, 2018. Available: https://www. undp.org/content/dam/bangladesh/docs/Publications/Pub-2019/ SDGs-Bangladesh_Progress_Report\%202018\%20(1).pdf

29 Perera W. Bangladesh government downplays COVID-19 threat as job losses mount, 2020.

30 World Health Organization. COVID-19 situation report 4. 2020.

31 Tribune D. Govt to recruit 2,654 health service providers for 6 months. Dhaka Tribune, 2020.

32 Mahara G, Yang K, Chen S, et al. Socio-economic predictors and distribution of tuberculosis incidence in Beijing, China: a study using a combination of spatial statistics and GIS technology. Med Sci 2018;6:26.

33 Kulldorff M. A spatial scan statistic. Commun Stat Theory Methods 1997;26:1481-96.

34 Kulldorff M. SaTScan user guide for version 9.02010.

35 Kulldorff M, Heffernan R, Hartman J, et al. A space-time permutation scan statistic for disease outbreak detection. PLoS Med 2005;2:e59.

36 The Business Standard. First coronavirus cases detected in Bangladesh 2020.

37 Worldometer. COVID-19 coronavirus pandemic, 2020. Available: https://www.worldometers.info/coronavirus/

$38 \mathrm{Sim} \mathrm{K}$, Chua HC, Vieta E, et al. The anatomy of panic buying related to the current COVID-19 pandemic. Psychiatry Res 2020;288:113015.

39 COVID-19 siatuation report \#4 [press release] 2020.

40 Masrur A, Yu M, Luo W, et al. Space-time patterns, change, and propagation of COVID-19 risk relative to the intervention scenarios in Bangladesh. Int J Environ Res Public Health 2020;17:5911.

41 Sarkar SK, Ekram KMM, Das PC. Spatial modeling of COVID-19 transmission in Bangladesh. Spatial Inform Res 2021;29:715-26.

42 Bangladesh Bureau of Statistics. Population and housing census 2011: national report, analytical report. Dhaka, Bangladesh: Bangladesh Bureau of Statistics, Ministry of Planning, 2011. 
43 Authority BIWT. Bangladesh regional waterway transport project 1 2016.

44 Bhadra A, Mukherjee A, Sarkar K. Impact of population density on Covid-19 infected and mortality rate in India. Model Earth Syst Environ 2021;7:623-9.

45 Pequeno P, Mendel B, Rosa C, et al. Air transportation, population density and temperature predict the spread of COVID-19 in Brazil. PeerJ 2020;8:e9322.

46 Kodera S, Rashed EA, Hirata A. Correlation between COVID-19 morbidity and mortality rates in Japan and local population density, temperature, and absolute humidity. Int J Environ Res Public Health 2020;17:5477.

47 Luo Y, Yan J, McClure S. Distribution of the environmental and socioeconomic risk factors on COVID-19 death rate across continental USA: a spatial nonlinear analysis. Environ Sci Pollut Res Int 2021;28:6587-99.

48 Coșkun H, Yıldırım N, Gündüz S. The spread of COVID-19 virus through population density and wind in turkey cities. Sci Total Environ 2021;751:141663.
49 Desai D. Urban densities and the Covid-19 pandemic: upending the sustainability myth of global megacities. ORF Occasional Paper 2020;244:1-4.

50 Hassan MM, Kalam MA, Shano S. Assessment of epidemiological determinants of COVID-19 pandemic related to social and economic factors globally. J Risk Financ Manag 2020;13:194.

51 Zhang Y, Jiang B, Yuan J, et al. The impact of social distancing and epicenter lockdown on the COVID-19 epidemic in mainland China: a data-driven SEIQR model study. MedRxiv 2020.

52 Rahman MH, Zafri NM, Ashik FR, et al. Identification of risk factors contributing to COVID-19 incidence rates in Bangladesh: a GISbased spatial modeling approach. Heliyon 2021;7:e06260.

53 Hamidi S, Sabouri S, Ewing R. Does density aggravate the COVID-19 pandemic? Early findings and lessons for planners. J Am Plan Assoc 2020;86:495-509.

54 Rahman MR, Islam AHMH, Islam MN. Geospatial modelling on the spread and dynamics of 154 day outbreak of the novel coronavirus (COVID-19) pandemic in Bangladesh towards vulnerability zoning and management approaches. Model Earth Syst Environ 2020:1-29. 